\title{
HUBUNGAN PERSONAL HYGIENE PENJAMAH MAKANAN DENGAN KUALITAS BAKTERIOLOGIS MPN COLIFORM PADA JAJANAN DI WILAYAH PASAR SEGAR PANAKUKANG KOTA MAKASSAR KHIKI PURNAWATI KASIM ${ }^{1}$ dan ANDI ADE MUSTIKA SARI ${ }^{2}$ \\ 1.2Poltekkes Kemenkes Makassar andiademustikas@gmail.com
}

\begin{abstract}
Diarrhea is a health problem in Indonesia, one of the food sources that is potentially contaminated with microbes is food. In the handling of food often don't pay attention to the personal hygiene factors of food handlers so potentially the occurrence of biological contamination. The purpose of this study is to know the relations of personal hygiene food handlers with the bacteriological quality MPN Coliform at food in Panakukang Segar market area Makassar city. Design using an analytic survey with cross approach sectional with 20 samples of merchants and 20 samples of food. Data from interviews, observation, an examination of bacteria coliform were analyzed using statistical test "extract fisher". Results showed personal hygiene food handlers as much as 1 respondent (5\%) including good category, while 19 respondents (95\%) including the bad category. Based on the bacteriological quality of MPN Coliform, there were 19 samples (95\%) that didn't meet the requirements and 1 sample (5\%) were eligible. The result of a statistical test using the test of exact fisher obtained $P=0.050<\alpha 0.05$ which means there is a relationship between personal hygiene food handlers with the bacteriological quality of MPN Coliform at food in Panakukang Segar market area Makassar city. This study concludes that there is a relationship between personal hygiene food handlers with the bacteriological quality of MPN Coliform at food in the Panakukang Segar market area. Suggestions for food handlers further enhance personal hygiene during food processing, especially in the use of gloves and masks

Keywords: Personal Hygiene, Food Handlers, Coliform, Food.
\end{abstract}

\section{ABSTRAK}

Diare merupakan masalah kesehatan di Indonesia, salah satu sumber makanan yang berpotensi tercemar mikroba adalah makanan jajanan. Dalam penanganan makanan jajanan sering tidak memperhatikan faktor kebersihan diri dari penjamah makanan sehingga berpotensi terjadinya cemaran biologi. Tujuan penelitian ini adalah untuk mengetahui hubungan personal hygiene penjamah makanan dengan kualitas bakteriologis MPN Coliform pada jajanan di wilayah pasar Segar Panakukang kota Makassar. Rancangan penelitian menggunakan desain survei analitik dengan pendekatan cross sectional dengan jumlah sampel 20 pedagang dan 20 sampel jajanan. Data dari hasil wawancara, observasi, pemeriksaan bakteri Coliform dianalisa menggunakan uji statistik "eksak fisher". Hasil penelitian menunjukkan personal hygiene penjamah makanan sebanyak 1 responden ( $5 \%$ ) termasuk kategori baik, sedangkan 19 responden (95\%) termasuk kategori buruk. Berdasarkan kualitas bakteriologis MPN Coliform terdapat 19 sampel ( $95 \%$ ) yang tidak memenuhi syarat dan 1 sampel ( $5 \%$ ) yang memenuhi syarat. Hasil uji statistik dengan menggunakan uji eksak fisher diperoleh nilai $\mathrm{P}=0,050<\alpha 0,05$ yang berarti ada hubungan antara personal hygiene penjamah makanan dengan kualitas bakteriologis MPN Coliform pada jajanan di wilayah pasar Segar Panakukang kota Makassar. Kesimpulan dari peneltian ini adalah ada hubungan antara personal hygiene penjamah makanan dengan kualitas bakteriologis MPN Coliform pada jajanan di wilayah pasar Segar Panakukang. Saran untuk penjamah makanan lebih meningkatkan personal hygiene pada saat proses pengolahan makanan terutama dalam penggunaan sarung tangan dan masker.

Kata Kunci : Personal Hygiene, Penjamah Makanan, Coliform, Jajanan

\section{PENDAHULUAN}

Makanan dalam tubuh mempunyai 3 fungsi yaitu makanan sebagai sumber energi, makanan sebagai sumber zat pembangun dan makanan sebagai sumber zat pengatur. Ketiga fungsi makanan sangat penting perannya masing masing dalam tubuh manusia (Chandra, 2005)

Fungsi makanan yang sangat penting dalam tubuh manusia, sehingga dalam menghasilkan makanan atau minuman tentunya harus memperhatikan kualitasnya. Aspek penting yang perlu diperhatikan adalah keamanan makanan dan minuman tersebut. Karena salah satu masalah kesehatan yang mungkin terjadi akibat mengkonsumsi makanan yang tidak berkualitas adalah diare dan keracunan makanan.

Diare merupakan masalah kesehatan di Indonesia, menurut Kemenkes RI (2016) untuk penemuan kasus diare di provinsi Sulawesi Selatan sebanyak 230.048 kasus diare dan
172.650 kasus diare yang ditangani ( $75,0 \%)$. Hal ini didukung pula berdasarkan data Badan Pusat Statistik (2016) jumlah kasus diare menempatkan kota Makassar dengan kasus terbanyak sebanyak 27.304 kasus. Dan jumlah penderita akibat penyakit diare menempatkan kecamatan Panakukang sebagai urutan pertama sebanyak 2.753 orang dan meninggal sebanyak 1 orang.

Menurut BPOM (2016) sendiri di Indonesia telah mencatat 110 berita keracunan pangan dan sebanyak 60 kejadian luar biasa (KLB) yang dilaporkan jumlah orang yang terpapar sebanyak 5.673 orang dengan 3.351 orang sakit dan 7 orang meninggal. Untuk provinsi Sulawesi Selatan terjadi sebanyak 7 kasus frekuensi KLB dengan penderita sakit sebanyak 135 orang dan mati 2 orang.

Penyakit bawaan makanan mencakup lingkup penyakit yang etiologinya bersifat kimiawi 
maupun biologis, termasuk penyakit kolera dan diare (Andry, 2005).

Salah satu sumber makanan yang berpotensi tercemar mikroba Coliform adalah makanan jajanan karena jajanan merupakan makanan dan minuman yang dipersiapkan dan dijual oleh pedagang di jalanan dan tempat tempat keramaian umum lainnya yang langsung dimakan dan dikonsumsi tanpa pengolahan dan persiapan semestinya.

Menurut penelitian Devi, et al., (2016) menunjukkan bahwa 15 sampel bakso bakar yang dijual di pasar Minggu kota Malang positif tercemar oleh bakteri Coliform. Pada penelitian lainnya dilaporkan oleh Lasinrang et al., (2015) bahwa makanan jajanan terdiri dari siomay mengandung 240 Coliform / gram dan batagor mengandung 1.100 Coliform / gram di pedagang kaki lima Kampus II Universitas Islam Negeri (UIN) Alauddin Makassar.

Berdasarkan Ririh et al., (2017) bahwa sebanyak $85 \%$ jajanan terdiri dari cilok dan gorengan mengandung Coliform di Sekolah Dasar wilayah kecamatan Tembalang Semarang dan ada hubungan praktik penjamah makanan dengan kontaminasi bakteri pada makanan jajanan dengan nilai $(p<0,05)$.

Berdasarkan survei pendahuluan di pasar Segar Panakukang dalam segi personal hygiene penjamah makanan terlihat tanpa menggunakan alat pelindung diri seperti celemek, penutup mulut dan melakukan kontak langsung dengan makanan tanpa menggunakan sarung tangan pada saat pengolahan, serta ada beberapa penjamah makanan tidak mencuci tangan sebelum menangani makanan. Hal lain yang menjadi pendukung adalah kondisi tempat pengolahan makanan yang berada dekat dengan tempat pembuangan limbah (kanal) dan tempat sampah dalam keadaan terbuka serta beberapa stan berada di pinggir jalan sehingga memungkinkan masuknya debu dari luar dan akan terkontaminasi kemakanan.

\section{Bahan dan Metode}

\section{Lokasi Penelitian}

Lokasi penelitian dilakukan di wilayah pasar Segar Panakukang kota Makassar dan untuk melakukan pemeriksaan kualitas bakteriologis MPN Coliform di laboratorium mikrobiologi Jurusan Kesehatan Lingkungan Politeknik Kesehatan Makassar

\section{Desain dan Variabel Penelitian}

Jenis penelitian yang digunakan adalah desain survei analitik dengan pendekatan cross sectional yaitu dimana variabel bebas dan variabel terikat dibandingkan secara bersamaan guna mengetahui hubungan antara personal hygiene dengan kualitas bakteriologis MPN Coliform pada jajanan yang dijual di wilayah pasar Segar Panakukang kota Makassar. Data dianalisa menggunakan uji statistik "eksak fisher".

Variabel dalam penelitian ini adalah variabel bebas yaitu personal hygiene penjamah makanan dan variabel terikat yaitu kualitas bakteriologis MPN Coliform dalam bentuk persentase tabel.

\section{Sampel}

Sampel pada penelitian ini adalah pedagang di wilayah pasar Segar Panakukang kota Makassar. Pada masingmasing sampel, yang diambil sebagai unit sampel adalah penjamah makanan sebanyak 20 pedagang dan 20 sampel jajanan.

\section{Pengumpulan Data}

\section{a. Data Primer}

Data primer merupakan data yang diperoleh dengan melakukan 3 cara yaitu hasil pemeriksaan bakteri Coliform, Mengadakan observasi langsung terhadap personal hygiene penjamah makanan dan mengadakan wawancara terhadap responden.

b. Data Sekunder

Data sekunder diperoleh melalui penelusuran kepustakaan berupa referensi hasil penelitian sebelumnya, jurnal, artikel, dan literatur lainnya dari situs internet berhubungan dengan objek penelitian maupun laporan pemerintah.

\section{Analisis Data}

Analisis data ditentukan untuk mengetahui hubungan antara variabel bebas dengan variabel terikat. Selain itu, analisis data dapat digunakan untuk menguji hipotesa penelitian. Dalam penelitian ini menggunakan uji statistik berupa uji eksak fisher guna mengetahui hubungan antara personal hygiene dengan kualitas bakteriologis MPN Coliform pada jajanan yang dijual di wilayah pasar Segar Panakukang kota Makassar.

\section{Hasil Penelitian}


Jurnal Sulolipu : Media Komunikasi Sivitas Akademika dan Masyarakat

Vol. 18 No 22018

e-issn : 2622-6960, p-issn: 0854-624X

Setelah melakukan penelitian yang bertujuan untuk mengetahui hubungan antara personal hygiene dengan kualitas bakteriologis MPN Coliform pada jajanan yang dijual di wilayah pasar Segar Panakukang kota Makassar.

1. Analisis Univariat

\section{a. Personal Hygiene}

Tabel 1

Distribusi Responden Tentang Personal

Hygiene Penjamah Makanan di Wilayah Pasar Segar Panakukang Kota Makassar

\begin{tabular}{cccc}
\hline No. & $\begin{array}{c}\text { Personal } \\
\text { Hygiene }\end{array}$ & Frekuensi & $\begin{array}{c}\text { Persentase } \\
(\%)\end{array}$ \\
\hline 1. & Baik & 1 & 5 \\
2. & Buruk & 19 & 95 \\
\hline & Jumlah & 20 & 100 \\
\hline
\end{tabular}

Sumber: Data Primer, 2018

\section{b. Kualitas Bakteriologis MPN Coliform pada Jajanan}

Tabel 2

Distribusi Responden Tentang Kualitas

Bakteriologis MPN Coliform pada Jajanan di Wilayah Pasar Segar Panakukang Kota Makassar

\begin{tabular}{cccc}
\hline No. & $\begin{array}{c}\text { Keberadaan } \\
\text { Coliform }\end{array}$ & $\begin{array}{c}\text { Frekuen } \\
\text { si }\end{array}$ & $\begin{array}{c}\text { Persentase } \\
\text { (\%) }\end{array}$ \\
\hline 1. & Memenuhi Syarat & 1 & 5 \\
2. & $\begin{array}{c}\text { Tidak Memenuhi } \\
\text { Syarat }\end{array}$ & 19 & 95 \\
\hline & Jumlah & 20 & 100 \\
\hline
\end{tabular}

Sumber: Data Primer, 2018

2. Analisis Bivariat

a. Hubungan Personal Hygiene dengan Kualitas Bakteriologis MPN Coliform pada Jajanan.

Tabel 3

Hubungan Personal Hygiene dengan Kualitas

Bakteriologis MPN Coliform pada Jajanan di Wilayah Pasar Segar Panakukang Kota Makassar

\begin{tabular}{|c|c|c|c|c|c|c|c|c|}
\hline \multirow{3}{*}{$\begin{array}{l}\text { Personal } \\
\text { Hygiene }\end{array}$} & \multicolumn{5}{|c|}{$\begin{array}{l}\text { Keberadaan Bakteri } \\
\text { Coliform }\end{array}$} & \multirow{3}{*}{$\%$} & \multirow{3}{*}{$\alpha$} & \multirow{3}{*}{$P$} \\
\hline & \multicolumn{2}{|c|}{$\begin{array}{l}\text { Meme } \\
\text { nuhi } \\
\text { Syarat }\end{array}$} & \multicolumn{2}{|c|}{$\begin{array}{l}\text { Tidak } \\
\text { Memenuh } \\
\text { i Syarat }\end{array}$} & \multirow[t]{2}{*}{$\begin{array}{l}\text { To } \\
\text { tal }\end{array}$} & & & \\
\hline & $\Sigma$ & $\%$ & $\Sigma$ & $\%$ & & & & \\
\hline Baik & 1 & 100 & 0 & 0,0 & 1 & 100 & & \\
\hline Buruk & 0 & 0,0 & 19 & 100 & 19 & 100 & $\begin{array}{l}0, \\
05\end{array}$ & $\begin{array}{l}0,0 \\
50\end{array}$ \\
\hline Total & 1 & 5,0 & 19 & $\begin{array}{l}95, \\
0\end{array}$ & 20 & 100 & & \\
\hline
\end{tabular}

Sumber: Data Primer, 2018

\section{Pembahasan}

Dalam pembahasan ini penulis akan menguraikan analisa hasil penelitian sebagai berikut:

1. Gambaran Personal Hygiene Penjamah Makanan

Personal hygiene merupakan kunci keberhasilan dalam menghasilkan kualitas makanan yang aman dan sehat. Berdasarkan hasil penelitian pada 20 pedagang jajanan mengenai personal hygiene penjamah makanan di wilayah pasar Segar Panakukang kota Makassar yang dilakukan oleh peneliti pada saat survei pendahuluan, observasi terhadap kebersihan penjamah makanan, dan pada saat pengambilan sampel jajanan.

Dapat dilihat pada tabel 5.1 terdapat 1 responden ( $5 \%$ ) dengan kategori baik dalam hal menangani makanan, sedangkan 19 responden ( $95 \%$ ) termasuk kategori buruk dalam menangani atau menjamah makanan.

Hal ini dapat terjadi karena para pedagang kurang memperhatikan kriteria kriteria personal hygiene yang harus dilakukan dalam menangani makanan.

Sejalan dengan penelitian Ratni (2012) tentang Aspek Hygiene di pasar Jajan kota Gorontalo bahwa personal hygiene penjamah makanan masih rendah yakni ( $42,86 \%)$. Ini dikarenakan banyaknya penjamah makanan yang tidak mencuci tangan sebelum menjamah / mengolah makanan ( $78,57 \%$ ), berbicara selama proses pengolahan makanan ( $85,71 \%$ ), kebersihan tangan ( $78,57 \%)$, dan tidak menggunakan celemek ( $100 \%)$.

Permasalahan yang paling banyak ditemukan pada pedagang yang ada di wilayah pasar Segar Panakukang kota Makassar adalah tidak melakukan cuci tangan menggunakan sabun sebelum dan sesudah menangani makanan yakni sebanyak 20 pedagang $(100 \%)$. Selain itu ditemukan pula sebanyak 16 pedagang ( $80 \%$ ) yang tidak mengeringkan tangan dengan lap bersih setelah mencuci tangan.

Kegiatan pencucian tangan sangat diperlukan sebelum dan sesudah menangani makanan karena mempunyai andil besar dalam mengkontaminasi makanan.

Menurut Hiasinta dalam Nur Laila (2011) dalam proses pencucian tangan perlu adanya langkah - langkah untuk menjamin kebersihan tangan guna terhindar dari mikroba - mikroba diantaranya membasahi tangan dengan air dan menggunakan sabun, 
menggosok tangan secara menyeluruh pada bagian - bagian meliputi punggung tangan, telapak tangan, sela - sela jari dan bagian di bawah kuku, dan melakukan pengeringan tangan dengan handuk atau alat pengering.

Kriteria lain yang menjadi masalah yakni dalam penggunaan alat pelindung diri (APD) pada pedagang seperti tidak menggunakan celemek yakni 20 pedagang ( $100 \%$ ), penggunaan pakaian bersih 12 pedagang ( $60 \%)$, tidak menggunakan penutup mulut sebanyak 17 pedagang ( $85 \%)$ ), sebanyak 10 pedagang ( $50 \%$ ) yang tidak menggunakan penutup kepala, serta dalam penggunaan sarung tangan diketahui 13 pedagang ( $65 \%$ ) yang tidak menggunakan APD tersebut.

Penggunaan APD seperti celemek, penutup mulut, sarung tangan ini yang masih jarang diterapkan diikuti oleh berbagai alasan diantaranya ketidaknyamanan dan kebiasaan dari penjamah. Kontaminasi silang terhadap makanan dapat terjadi apabila penggunaan APD ini tidak diterapkan utamanya dalam hal ini penggunaan celemek dan sarung tangan.

Permasalahan lain di wilayah pasar Segar Panakukang terkait personal hygiene penjamah makanan yakni kebiasaan buruk yang dilakukan oleh penjamah. Dari hasil penelitian dapat diketahui sebanyak 10 pedagang ( $50 \%$ ) melakukan kebiasaan merokok, kebiasaan berbicara saat mengolah makanan yakni 11 pedagang (55\%), kebiasaan menerima / memegang sumber kontaminasi dari pembeli setelah mengolah / menyajikan makanan yakni 14 pedagang $70 \%), 12$ pedagang ( $60 \%$ ) ditemukan kebersihan tangan dalam keadaan kotor (kuku), serta faktor terakhir yakni sebanyak 11 pedagang ( $65 \%$ ) yang melakukan kebiasaan tidak melepas perhiasan saat bekerja.

Penelitian yang dilakukan oleh Ratni (2012) juga ditemukan dari 14 pedagang yang terdapat 12 pedagang ( $85,17 \%$ ) yang berbicara. Sedangkan penelitian ini berbanding terbalik dengan penelitian yang dilakukan Dikry (2015) dari 10 pedagang hanya 1 pedagang ( $10 \%$ ) yang melakukan kebiasaan merokok dan ( $77,8 \%$ ) penjamah makanan memiliki kuku dengan kondisi pendek dan bersih.

Pada saat penelitian kebiasaan lain yang ditemukan yakni menggaruk anggota badan saat bekerja sebanyak 10 pedagang ( $50 \%$ ) dan tidak menutup luka pada tubuh sebanyak 1 pedagang ( $5 \%$ ).
Kebiasaan - kebiasaan yang tidak disadari ini mempunyai peluang melakukan perpindahan kontaminan dari manusia kemakanan. Utamanya kebiasaan berbicara dan memiliki kuku yang panjang saat mengolah makanan.

Kesadaran penjamah makanan terkait kebiasaan - kebiasaan yang tidak disadari saat mengolah makanan ini dapat diminimalisir dengan penggunaan alat pelindung diri seperti penggunaan masker dan sarung tangan dimana dapat menjadi lebih efektif untuk menahan penyebaran bakteri dan virus ( Kemenkes RI, 2014 )

\section{Kualitas Bakteriologis MPN Coliform pada Jajanan}

Berdasarkan pemeriksaan di laboratorium Mikrobiologi Jurusan Kesehatan Lingkungan didapatkan hasil dari 20 sampel jajanan di wilayah pasar Segar Panakukang kota Makassar, 18 sampel jajanan berbahan olahan daging (kebab, bakso, dan bakso bakar) seluruhnya tidak memenuhi syarat dan 2 sampel jajanan berbahan bumbu (sate) ditemukan 1 sampel jajanan yang tidak memenuhi syarat dan 1 sampel yang memenuhi syarat. Hal ini didasarkan pada peraturan Standar Nasional Indonesia (SNI) No. 7388 - 2009 tentang batas maksimum cemaran mikroba bahwa kandungan bakteri Coliform pada olahan daging yaitu 10 / gr dan kandungan bakteri Coliform pada bahan bumbu yaitu $1 \times 10^{2}$ koloni / gr.

Sehingga dapat ditarik kesimpulan bahwa 19 sampel ( $95 \%$ ) yang memenuhi syarat dan 1 sampel ( $5 \%$ ) yang yang tidak memenuhi syarat.

Hal ini sesuai dengan penelitian Devi, et al., (2016) menunjukkan bahwa 15 sampel bakso bakar yang dijual di pasar Minggu kota Malang tidak memenuhi syarat sehingga positif tercemar oleh bakteri Coliform.

Keberadaan bakteri Coliform pada 19 sampel jajanan menunjukkan bahwa kebanyakan penjamah makanan tidak melakukan pencucian tangan dengan sabun sebelum dan sesudah mengolah makanan serta tidak mengeringkan tangan dengan lap bersih, tidak menggunakan alat pelindung diri seperti penggunaan celemek, penutup mulut / masker, sarung tangan, dan penutup kepala.

Keberadaan adanya bakteri Coliform pada sampel jajanan juga dapat terjadi karena kebiasaan penjamah makanan berbicara, 
menggaruk anggota badan, dan kebiasaan memegang sumber kontaminasi dari pembeli setelah mengolah / menyajikan makanan, serta kurang menjaga kebersihan tangan. Pada saat di lapangan peneliti menemukan pedagang yang berbicara saat pengolahan utamanya pada pedagang bakso bakar dan sate karena jajanan ini yang memiliki proses pengolahan pembakaran dan membutuhkan waktu yang lama.

Hampir sebagian besar penjamah makanan yang melakukan pengolahan makanan dan juga melakukan transaksi dengan pembeli sehingga kebiasaan memegang sumber kontaminasi terjadi dan dapat menjadi faktor adanya keberadaan bakteri Coliform.

Selain dari segi kebersihan diri penjamah ada berbagai faktor yang menyebabkan adanya bakteri Coliform salah satunya tempat penyimpanan bahan makanan bakso bakar dan sate sendiri dibiarkan bertumpuk dan belum teratur, serta terbuka tanpa adanya penutup. Pada jajanan seperti kebab dan bakso bakar tidak menyimpan bahan sayuran dan bakso di lemari pendingin / kulkas. Penyimpanan bahan bakso pada suhu ruang sehingga memungkinkan kontaminasi yang terjadi sangat tinggi dan pertumbuhan bakteri sangat cepat karena suhu optimal untuk pertumbuhan. Pedagang tidak mencuci bahan sayur sebelumnya dan hanya menyimpan sayur di wadah seperti keranjang yang terbuka, sedangkan bahan bakso yang belum matang hanya disimpan di atas pembakaran dalam waktu lama tanpa penutup. Tetapi sebagian pedagang adapula ditemukan menyimpan bahan makanan seperti bakso di dalam lemari es. Bahwa sayur - sayuran dan daging tergolong dalam makanan yang mudah rusak sehingga perlu disimpan lebih teliti dan hati hati agar tidak cepat rusak. Suhu penyimpanan bahan makanan yang mudah rusak dalam lemari es $4,4^{\circ} \mathrm{C}$. Tempat penyimpanan bahan makanan selalu terpelihara dan dalam keadaan bersih, terlindung dari debu, bahan kimia berbahaya, serangga dan hewan lainnya.

Faktor lain yang menyebabkan keberadaan bakteri Coliform yakni ditinjau segi jenis jajanan. Jajanan seperti bakso bakar dan kebab yang umumnya ditambahkan saus cabai sebagai pelengkap menjadi salah satu faktor adanya bakteri Coliform yang ditambahkan pada jajanan bakso bakar sehingga mempengaruhi kualitas makanan.
Saus cabai merupakan bahan tambahan makanan (BTM) yang biasanya terbuat dari tomat busuk yang kemudian dicampur dengan bahan pengawet seperti formalin dan dapat berbahaya bagi kesehatan apabila dikonsumsi (Metatia, 2014)

Bahan bumbu kacang menjadi hal yang dapat mempengaruhi adanya bakteri Coliform pada jenis jajanan sate. Adanya kandungan air yang dicampurkan pada olahan bumbu kacang pada sate juga merupakan faktor adanya bakteri Coliform. Pada saat penelusuran untuk melihat pembuatan bumbu pada sate dilihat air yang digunakan yakni air yang belum dimasak sebelumnya dan langsung dicampurkan pada olahan bumbu kacang untuk sate.

Faktor lain yang yakni dilihat dari segi kondisi tempat. Sebanyak 17 pedagang ( $85 \%$ ) menjajakan makanan jajanan seperti bakso bakar di area terbuka. Pedagang yang menyediakan tempat sampah 19 pedagang ( 95\% ) namun dalam keadaan tidak tertutup dan 10 pedagang $(50 \%)$ yang memiliki tempat sampah namun dekat dengan tempat penjualan.

Berdasarkan pengamatan di lapangan sebagian besar pedagang memiliki kondisi tempat yang berbentuk stan pada area terbuka dan hanya bahan pembatas seperti terpal yang menutupi area pengolahan makanan serta dekat dengan sumber pencemaran misalnya ada beberapa tempat penjualan pedagang berada dekat dengan tempat pembuangan limbah (kanal) dan tempat sampah yang terbuka dan kotor, serta tidak menggunakan penutup dan area tersebut dekat dengan area pencucian. Dimana peralatan makanan / minuman yang ingin dicuci langsung diletakkan di tanah tanpa adanya wadah atau tempat area pencucian peralatan yang khusus. Hal ini yang menyebabkan adanya vektor seperti lalat di area sekitar penjualan. Dan beberapa penjual bakso bakar terlihat mencuci tusuk bakso dan sate pada air ember sekitar penjualan yang dilihat dari fisik telah digunakan berulang kali dan terlihat tusuk - tusuk sate dibiarkan berserakan di lantai pada saat pengolahan makanan berlangsung.

Sebaiknya pedagang selalu menjaga ketersediaan sumber air untuk mencuci peralatan dengan cukup, memisahkan air untuk proses pencucian dan pembilasan dengan bak terpisah memperhatikan sumber air bersih yang digunakan untuk mencuci 
peralatan dengan cara tidak menggunakan air tersebut secara berulang kali sampai kotor dan berminyak - minyak untuk mengurangi kontaminasi makanan.

Peralatan makanan / minuman harus terbuat dari bahan yang kuat dan bagian permukaan tempat makanan atau kontak dengan makanan permukaannya halus. Kebersihan peralatan harus dijaga dengan baik dengan memperhatikan secara fisik tidak adanya kotoran atau noda, tidak berbau (Cecep, 2015)

Dari segi lokasi pedagang misalnya penjual bakso bakar dan sate yang melakukan proses pembakaran di pinggir jalan dan dilalui oleh kendaraan yang mengeluarkan pencemaran seperti debu.

Bahan pangan dapat tercemar mikroorganisme terutama dari lingkungan sekitarnya seperti udara, air, tanah, debu, kotoran, ataupun bahan organik yang telah busuk.

Untuk tempat pembuatan makanan diperoleh sebanyak 18 pedagang ( $90 \%$ ) dalam keadaan tidak bersih dari bahan - bahan pencemar misalnya lantai dan dinding pada ruang pengolahan terlihat kotor begitu pula pada meja yang digunakan untuk memotong daging sate. Sebelum dan setelah meja digunakan tidak dibersihkan terlebih dahulu. Seperti dilihat pada pedagang seperti pedagang sate ruang dapur yang terlihat kotor pada dinding serta pada area mengolah bumbu dan area pemotongan daging.

Tempat pengolahan makanan (TPM) mempunyai potensi yang cukup besar untuk menyebabkan gangguan kesehatan atau penyakit bahkan keracunan akibat dari makanan yang dihasilkannya. Salah satu syarat kesehatan TPM yang penting dan mempengaruhi kualitas higiene sanitasi makanan tersebut adalah faktor lokasi dan bangunan TPM. Lokasi dan bangunan yang tidak memenuhi syarat kesehatan akan memudahkan terjadinya kontaminasi makanan oleh mikroorganisme seperti bakteri, jamur, virus dan parasit serta bahan - bahan kimia yang dapat menimbukan risiko terhadap kesehatan.

Maka dari itu perbaikan sarana tempat pengolahan makanan merupakan hal penting dalam mencegah adanya kontaminasi oleh bakteri kemakanan. Adapun perbaikan sarana TPM yang dapat dilakukan salah satunya yaitu terlindung dari sinar matahari, hujan dan angin, tidak menjadi tempat bersarangnya vektor dan binatang pengganggu, jika ditinjau dari segi konstruksi tempat sampah yang seharusnya diterapkan adalah terbuat dari bahan yang kuat, kedap air, tertutup, dan memakai kantong plastik khusus untuk sisa-sisa bahan makanan dan makanan jadi yang cepat membusuk.

\section{Hubungan Personal Hygiene dengan Kualitas Bakteriologis MPN Coliform pada Jajanan}

Berdasarkan hasil penelitian diperoleh ada hubungan antara personal hygiene penjamah makanan dengan kualitas bakteriologis (Coliform) pada jajanan di wilayah Pasar Segar Panakukang Kota Makassar. Hasil ini didasarkan pada uji Eksak Fisher diperoleh nilai $p$ value $=0,050<\alpha=0,05$.

Adanya hubungan ini dapat dilihat pada tabel 5.3, dimana dari 1 responden yang personal hygiene dalam kategori baik, terdapat 1 sampel jajanan yang memenuhi syarat. Sedangkan dari 19 responden yang personal hygiene dalam kategori buruk, diketahui bahwa 19 sampel tersebut seluruhnya tidak memenuhi syarat. Hal ini menunjukkan jika personal hygiene penjamah masih dalam kategori buruk maka jajanan yang diolah tidak memenuhi syarat atau terdapatnya bakteri Coliform.

Hasil penelitian ini sesuai dengan penelitian yang dilakukan Ririh et al., (2017) bahwa sebanyak $85 \%$ jajanan terdiri dari cilok dan gorengan mengandung Coliform di Sekolah Dasar wilayah kecamatan Tembalang Semarang dan ada hubungan praktik penjamah makanan dengan kontaminasi bakteri pada makanan jajanan.

Ada beberapa faktor yang dapat menyebabkan adanya bakteri Coliform salah satunya dari personal hygiene penjamah makanan. Beberapa kriteria yang telah ditetapkan berdasarkan Keputusan Menteri Kesehatan No 942 Tahun 2003 tentang pedoman persayaratan hygiene sanitasi makanan jajanan dan dimana kriteria - kriteria yang tercantum selanjutnya diobservasi kepada responden dalam hal ini personal hygiene penjamah makanan bahwa sebagian besar responden tidak memenuhi kriteria tersebut (terlampir)

Berdasarkan hasil penelitian dari beberapa kriteria yang dijadikan acuan dalam melihat praktik personal hygiene penjamah makanan diperoleh beberapa faktor yang sangat berpotensi mengakibatkan adanya 
bakteri Coliform pada makanan yakni faktor pertama pedagang terlihat tidak mencuci tangan menggunakan sabun setiap kali hendak menangani makanan yakni sebanyak 20 pedagang $(100 \%)$ ini terjadi karena tidak adanya tersedia sarana cuci tangan pada area sekitar pengolahan makanan hanya menggunakan ember biasa dalam hal melakukan kegiatan pencucian, umumnya pedagang hanya mengelap tangan dengan menggunakan kain yang belum terlihat bersih. Saat pengamatan tangan penjamah makanan yang tidak diketahui kebersihannya digunakan langsung untuk menyentuh makanan seperti memasukkan daging bakso maupun sate kedalam tusukan.

Hal ini sejalan dengan penelitian Endah (2013) bahwa sebanyak ( $76,9 \%$ ) pedagang yang tidak mencuci tangan sebanyak 7 pedagang ( $53,8 \%)$ mengaku tidak menggunakan sabun dalam mencuci tangan.

Tangan yang kotor atau terkontaminasi dapat memindahkan bakteri dan virus patogen dalam tubuh. Kebiasaan tangan ini dikaitkan dengan pergerakan - pergerakan tangan yang tidak disadari seperti menyentuh sumber kontaminan misalnya uang, pakaian yang digunakan, rambut, pada saat menggaruk anggota badan misalnya hidung, mulut, telinga atau bagian yang lainnya serta hal - hal lain yang serupa.

Mencuci tangan dengan sabun sangat perlu karena mengandung bahan aktif triklosan yang dapat berfungsi sebagai antimikroba diikuti dengan pembilasan sebelum mengolah makanan dianggap efektif dalam mengurangi risiko kontaminasi bakteri patogen. Berperilaku higienis dan saniter perlu dilakukan setiap melayani konsumen, antara lain selalu mencuci tangan dengan sabun setiap melayani konsumen untuk mencegah pencemaran (Permenkes, 2014)

Untuk itu penggunaan alat pelindung diri seperti sarung tangan pada penjamah makanan merupakan alternatif paling mudah dalam mencegah kontaminasi dari tangan ke makanan dan lebih memperhatikan pengantian air untuk pencucian tangan.

Faktor kedua yang menyebabkan adanya bakteri Coliform adalah penggunaan pakaian bersih dan penggunaan celemek. Responden yang menggunakan pakaian bersih yakni sebanyak 12 pedagang $(60 \%)$ dan sebanyak 20 pedagang ( $100 \%$ ) yang tidak menggunakan celemek.

Walapun telah menggunakan pakaian bersih namun dalam praktiknya banyak penjamah makanan yang tidak menggunakan celemek saat mengolah makanan sehingga dapat mencemari makanan yang dihasilkan. Pemakaian celemek yang tidak diterapkan dapat menjadi faktor kontaminasi terhadap makanan apabila pakaian penjamah yang kotor dan berkeringat ketika mengolah makanan dapat terjadi kontaminasi silang terhadap makanan jika tanpa sengaja menyentuh pakaian pada saat menyajikan makanan, dan penggunaan celemek berperan dalam menimilisir hal tersebut. Dilihat pada saat observasi terutama pada pada penjamah makanan berjenis kelamin laki-laki yang dominan menggunakan kaos yang terlihat kotor.

Penggunaan celemek dan pakaian bersih merupakan salah satu kriteria personal hygiene. Pakaian yang digunakan seharusnya digunakan adalah yang berlengan, menutupi bahu dan ketiak pekerja. Pakaian kerja dibedakan dengan pakaian harian, disarankan ganti setiap hari. Pakaian dipilih model yang dapat melindungi tubuh pada waktu memasak, mudah dicuci bewarna terang / putih. Umumnya pakaian yang berwarna terang atau putih sangat dianjurkan terutama bekerja di bagian pengolahan. Hal ini disebabkan karena warna putih akan lebih mudah terdeteksi adanya kotoran yang mungkin terdapat pada pakaian dan berpotensi untuk menyebar pada makanan yang sedang diolah. Disamping itu ukur pakaian hendaknya pas dan tidak terlalu besar. Pakaian yang terlalu besar bisa berbahaya karena dapat berperan sebagai pembawa kotoran yang akan menyebabkan kontaminasi adanya bakteri.

Permasalahan lain pada penjamah makanan dan menjadi faktor berikutnya yakni sebanyak 16 pedagang ( $80 \%)$ setelah mencuci tangan mereka mengeringkan tangan bukan menggunakan lap bersih. Dimana dilakukan dalam waktu tiga kali pengamatan, dan melalui wawancara kepada responden hanya dicuci dua minggu sekali atau ketika sudah kotor saja ini dapat dilihat pada pedagang yang menjajakan dagangan bakso dan sate yang dimana menggunakan lap yang terlihat kotor. Sedangkan sebanyak 13 pedagang ( $65 \%$ ) pedagang jajanan tidak menggunakan sarung tangan. Pada penjual 
bakso saat ingin mengambil mie ataupun bahan lain dan pedagang jajanan kebab saat mengambil sayur isi kebab tidak menggunakan penjepit namun langsung dengan menggunakan tangan. Dapat dilihat penjual dagangan seperti sate dan bakso bakar langsung menggunakan tangan yang belum terjamin kebersihannya dalam memotong dan memasukkan daging pada tusukan maupun dalam mengolah bumbu sate biasanya mencicipi atau menyentuh makanan dengan tangan atau jari. Sentuhan tangan merupakan penyebab yang paling umum terjadinya pencemaran makanan.

Hal ini senada dengan penelitian yang dilakukan oleh Agustina et,al., (2010) diketahui bahwa sebanyak ( $69,6 \%$ ) pedagang makanan jajanan menjamah makanan dengan tangan tanpa alas atau perlengkapan lainnya.

Alat pelindung diri utamanya sarung tangan sangat diperlukan dan penggunaan sarung tangan sebaiknya hanya digunakan sekali pakai apabila terbuat dari bahan plastik. Untuk penggunaan alat penjepit juga sangat dibutuhkan oleh penjamah makanan dan harus selalu diperhatikan kebersihan peralatannya. Penggunaan alat pelindung diri seperti sarung tangan diperlukan sebagai salah satu pencegahan kontaminasi adanya bakteri Coliform pada saat mengolah makanan.

Masalah kebersihan tangan penjamah makanan perlu diperhatikan seperti tangan yang kotor dan berkuku panjang. Berdasarkan hasil penelitian sebanyak 12 pedagang (60\%) yang diamati berkuku panjang. Pada sela-sela jari dan kuku yang panjang dan kotor dapat menyimpan bakteri sehingga dapat mengkotaminasi makanan yang diolah.

Kuku yang terawat dan bersih juga merupakan cerminan kepribadian seseorang. Ujung-ujung kuku yang panjang dan tidak terawat merupakan tempat yang mudah kotor dan lembab sehingga akan menjadi tempat melekatnya berbagai kotoran yang mengandung berbagai bahan dan mikroorganisme salah satunya bakteri Coliform. Sehingga kuku pekerja harus selalu bersih, dipotong pendek, dan sebaiknya tidak dicat.

Hal lain yang dapat mempengaruhi yakni berbicara selama proses mengolah makanan sebagian besar pedagang yaitu sebanyak 11 pedagang ( $55 \%$ ) masih tetap berbicara baik berkomunikasi dengan rekan kerja maupun dengan pembeli sendiri selama dalam mengolah makanan. Sebanyak 17 pedagang ( $85 \%$ ) yang tidak menggunakan penutup mulut serta sebanyak 10 pedagang ( $50 \%$ ) melakukan kebiasaan merokok. Mulut juga merupakan salah satu sumber mikroba, khususnya pada penjamah makanan yang menderita penyakit seperti batuk.

Pada saat dilapangan peneliti menemukan kebiasaan merokok ini ditemukan pada penjamah makanan laki-laki, pada saat menjajakan makanannya penjamah makanan tersebut ada yang sambil merokok. Dimana tanpa disadari ketika tangan menyentuh bibir dan setelah itu langsung menyentuh makanan maka akan terjadi kontaminasi silang.

Begitu pula halnya penjamah makanan tidak menyadari bahwa berbicara selama mengolah makanan akan meningkatkan peluang tersebarnya penyakit yang dibawa oleh liur yang kemungkinan bisa masuk kedalam makanan yang diolah sehingga yang memicu adanya bakteri Coliform.

Untuk menghindari hal tersebut, dianjurkan bagi pedagang hendaknya menggunakan masker atau penutup mulut pada saat mengolah makanan dan minuman (Kemenkes RI, 2014)

Kebiasaan lain yang sering dilakukan oleh penjamah makanan jajanan yang ada yakni penjamah menerima dan memegang sumber kontaminasi seperti uang dari pembeli setelah mengolah atau menyajikan makanan, berdasarkan hasil penelitian diperoleh 14 pedagang $(70 \%)$ yang melakukan hal tersebut.

Dimana penjamah makanan yang mengolah makanan jajanan mereka pula yang melakukan aktivitas kegiatan transaksi kepada pembeli. Sehingga hal ini juga dapat menjadi salah satu yang memicu terjadinya kontaminasi dari uang yang menjadi sumber bakteri ketangan penjamah yang akan mengolah makanan sehingga ditemukan adanya bakteri Coliform pada makanan jajanan.

Sebanyak 11 pedagang ( 55\%) yang memakai perhiasan saat bekerja. Pada saat di lapangan diamati beberapa penjamah makanan menggunakan perhiasan pada saat mengolah makanan terutama perhiasan gelang dan cincin seperti pada kegiatan memasukkan daging bakso dan sate ke tusukan. Hal dapat menimbulkan kontaminasi karena bersentuhan langsung dengan makanan yang diolah namun tanpa diketahui bahwa kulit di bagian bawah perhiasan seringkali menjadi tempat yang 
subur dan tumbuh berkembang biaknya bakteri.

Penggunaan perhiasan misalnya cincin, kalung, anting, dan jam tangan sebaiknya dilepas sebelum pekerja memasuki daerah pengolahan makanan.

Begitu pula dengan penggunaan penutup kepala hanya sebanyak 10 pedagang ( $50 \%$ ), hal ini bisa terjadi kontaminasi silang apabila rambut dibiarkan dalam proses mengolah makanan. Berdasarkan pengamatan hampir sebagian besar penjamah makanan tidak menggunakan penutup kepala terutama dominan ditemukan pada penjamah makanan berjenis kelamin laki - laki. Meskipun rambut yang jatuh bukan penyebab utama kontaminasi bakteri, tetapi adanya rambut dalam makanan atau minuman dapat mengurangi nilai estetika dari makanan itu sendiri.

Menurut Hiasinta (2006) rambut pekerja harus selalu dicuci secara periodik. Selama mengolah atau menyajikan makanan harus dijaga agar rambut tidak terjatuh dalam makanan. Oleh karena itu pekerja yang berambut panjang harus mengikat rambutnya, dan disarankan menggunakan topi atau jala rambut (hairnet).

Pada penjamah yang memiliki luka pada tubuhnya harus menutup luka tersebut dengan pelindung yang kedap air seperti plester, berdasarkan hasil penelitian hanya 1 pedagang $(5 \%)$ yang dilihat tidak menutup luka pada tubuh yakni luka bekas gatal pada tubuh. Berdasarkan hasil wawancara terhadap beberapa penjamah makanan mengaku bahwa jika mereka mempunyai luka pada tubuh maka akan diperban / ditutup. Luka pada tubuh yang terdapat bakteri menjadi salah satu yang dapat berpotensi dalam mengkontaminasi makanan karena mungkin penjamah menggaruk atau menyentuh luka tersebut.

Pekerja yang memiliki luka pada tubuhnya harus menutup luka tersebut dengan pelindung yang kedap air, misalnya plester atau sarung tangan plastik untuk menjamin tidak berpindahnya mikroba yang terdapat pada luka kedalam makanan.

Berdasarkan hasil penelitian dilihat dari karaketristik responden sebanyak 14 pedagang berjenis kelamin perempuan dan diperoleh 6 orang berjenis kelamin laki-laki.

Dari umur responden diperoleh dominan berumur 22 - 51 tahun. Karakteristik responden selanjutnya dilihat pada masa kerja $\geq 5$ tahun diperoleh sebanyak 3 pedagang dan
$<5$ tahun sebanyak 17 pedagang. Untuk pendidikan yang dianut oleh pedagang dominan SMA / Sederajat yakni 13 pedagang sedangkan 7 pedagang lainnya hanya sebatas sampai SD dan SMP.

Penjamah makanan merupakan sumber utama kontaminasi makanan. Tangan, mulut, rambut, dan kulit dapat mencemari makanan. Kontaminasi makanan tersebut dapat berasal dari berbagai macam sumber kontaminasi silang (Arnia, 2013)

Adanya bakteri Coliform dalam makanan atau minuman dapat digunakan sebagai indikator keberadaan organisme patogen seperti bakteri yang berbahaya bagi kesehatan. Bayi, anak - anak beberapa orang tua dan orang-orang dengan sistem kekebalan tubuh yang terganggu mungkin lebih rentan terhadap penyakit seperti diare.

Diare yang diakibatkan oleh adanya bibit penyakit dalam makanan merupakan penyebab utama mal nutrisi, bahkan dapat menyebabkan kematian (WHO, 2014).

Penelitian yang dilakukan Maria (2018) menunjukkan bahwa adanya hubungan antara konsumsi makanan jajanan dengan diare dengan nilai $P=0,009$.

Maka dari itu keberadaan bakteri Coliform dalam makanan ataupun minuman jajanan sangat perlu diwaspadai. Masyarakat dalam memilih makanan harus peduli terhadap personal hygiene penjamah makanan serta sanitasi makanan atau minuman seperti kondisi kebesihan tempat dari pedagang sehingga hal ini merupakan salah satu cara mencegah masuknya bakteri Coliform kedalam tubuh.

\section{Kesimpulan dan Saran \\ 1. Kesimpulan}

a. Personal hygiene pada penjamah makanan terdapat 1 responden ( $5 \%$ ) termasuk kategori baik sedangkan 19 responden ( $95 \%$ ) termasuk kategori buruk.

b. Kualitas bakteriologis MPN Coliform pada jajanan terdapat 19 sampel ( $95 \%$ ) yang tidak memenuhi syarat dan sebanyak 1 sampel ( $5 \%$ ) yang memenuhi syarat.

c. Ada hubungan antara personal hygiene penjamah makanan dengan kualitas bakteriologis MPN Coliform pada jajanan di wilayah pasar Segar Panakukang kota Makassar 


\section{Saran}

a. Penjamah makanan hendaknya meningkatkan praktik personal hygiene dalam menangani makanan terutama dalam mencuci tangan dan dalam penggunaan Alat Pelindung Diri (APD) seperti sarung tangan dan masker serta meningkatkan kebersihan tempat penjualan para pedagang.

b. Dalam memilih makanan jajanan hendaknya masyarakat memperhatikan dan mempertimbangkan kondisi personal hygiene dan sarana sanitasi pedagang.

\section{DAFTAR PUSTAKA}

Djibran, A., Isa, I., \& Sihaloho, M. 2015. Fitoremediasi Air Yang Terkontaminasi Fosfat Dengan Menggunakan Tanaman Teratai (Nymphea Sp). (Online) : http://eprints.ung.ac.id/10354/. Diakses pada tanggal 5 Januari 2017.

Hadiyanto, \& Christwardana, M. 2012. Aplikasi Fitoremediasi Limbah Jamu Dan Pemanfaatannya Untuk Produksi Protein. (Online): https://www.academia.edu/5829385/APLI KASI_FITOREMEDIASI_LIMBAH_JAMU_DAN_PEMANFAATANNYA_UNTUK_PRODUKSI _PROTTEIN. Diakses pada 10 Januari 2017.

Jenie, B. S. L., \& Rahayu, W. P. 1996. Penanganan Limbah Industri Pangan. Yogyakarta: Kanisius.

Muhajir, M. S. (2013). Penurunan Limbah Cair BOD dan COD pada Industri Tahu Menggunakan Tanaman Cattail

(Typha

Angustifolia) dengan Sistem Constructed Wetland.(Online): http://lib.unnes.ac.id/18265/1/4 350408054.pdf. Diakses pada tanggal 10 Januari 2017.

Nindra, D. Y., \& Hartini, E. 2015. Efektivitas Tanaman Teratai (Nympahea Firecrest) Dan Eceng Gondok (Eichhornia Crassipes) dalam Menurunkan Kadar BOD (Biochemical Oxygen Demand) pada Limbah Cair Industri Tahu. Jurnal Kesehatan. (Online): http://publikasi.dinus.ac.id/index.php/visikes/article/view/1197/900. Diakses pada tanggal 13 Januari 2017.

Rahmah, \& Mulasari, S. A. 2015. Pengaruh Metode Koagulasi, Sedimentasi dan Variasi Filtrasi terhadap Penurunan Kadar TSS, COD dan Warna pada Limbah Cair Batik. (Online): https://doi.org/http://journal.uad.ac.id/index.php/CHEMICA/article/view/4560/3055. Diakses pada tanggal 5 Januari 2017

Republik Indonesia. 2010. Peraturan Gubernur Sulawesi Selatan Nomor: 69 Tahun 2010 Tentang Baku Mutu dan Kriteria Kerusakan Lingkungan Hidup.

Siswandari, A. M., \& Hindun, I. 2016. Echinodorus Paleafolius Sebagai Tanaman Fitoremedian Dalam Menurunkan Phospat Limbah Cair Laundry. (Online): https://media.ne liti.com/media/publications/117737-ID-none.pdf. Diakses pada tanggal 17 Januari 2017. 